\title{
ANALISA VALUASI EMITEN KARYA LISTED IDX
}

\author{
M. Aditya Ananda ${ }^{1}$
}

\begin{abstract}
This study aims to analyze the stock valuation of construction issuers, especially BUMN Karya using data for the first quarter - third quarter of 2020 obtained from financial statements. The ratio used is the valuation ratio such as Price to Book Value and Price to Earning to Share. The solvency ratio used is the Debt to Equity Ratio and the market cap value. The three construction issuers that are the focus of the analysis are PT Waskita Karya (WSKT), Tbk, PT Wijaya Karya, Tbk (WIKA), PT. Pembangunan Perumahan, Tbk (PTPP) and PT Adhi Karya (Persero) Tbk. The results of the analysis obtained in the third quarter of 2020, WSKT has a value of PBV 0.84, PER -7.56, DER 3.87 with a Market Cap of 19.9T. WIKA has a value of PBV 1.00, PER 320.79, DER 2.80 and Market Cap 16.1T. while PTPP, has PBV 0.66, PER 358.82, DER 2.79, Market Cap 9.4T. among the three issuers, WSKT has a negative value due to having a corrected profit in the third quarter of 2020. While the lowest PBV is owned by PTPP while the highest DER is owned by WSKT.
\end{abstract}

Keywords: Valuation Ratio, Debt to Equity Ratio, Market Valuation

\footnotetext{
${ }^{1}$ STAIN Teungku Dirundeng Meulaboh, royleesama@gmail.com
} 


\section{PENDAHULUAN}

Menjelang akhir 2020, melalui media - media, baik media elektronik maupun cetak, masyarakat segala lapisan tidak asing lagi mendengar omnibus law UU Cipta kerja. UU Cipta Kerja ini kemudian disahkan pada tanggal 2 November 2020 oleh presiden jokowi. Untuk melaksanakan UU Cipta kerja ini, tentunya UU ini perlu dijabarkan dalam bentuk Peraturan Pemerintah. Penjabaran yang lebih teknis dan spesifik maka diterbitkan peraturan turunan amanat dari UU cipta kerja ini. pada akhirnya, PP tersebutpun telah diterbitkan yang ditandatangani Pada tanggal 14 Desember 2020, Peraturan turunan UU Cipta kerja ini ditandatangani oleh Presiden Joko Widodo. PP tersebut yaitu peraturan pemerintah (PP) nomor 74 tahun 2020 tentang Lembaga Pengelola Investasi (setkab.go.id, 2020). Peraturan pemerintah (PP) nomor 74 tahun 2020 merupakan peraturan turunan dari pada UU no 11 Tahun 2020 tentang Cipta Kerja. Pada pasal 165 UU Cipta kerja ayat 1 disebutkan, dalam rangka pengelolaan investasi maka dibentuk lembaga pengelola investasi. Pada tahun 2021 Lembaga Pengelola Investasi atau Sovereign Wealth Fund (SWF) dibentuk ditengah masih berlangsungnya pandemi corona sejak 2019. SWF akan mulai beroperasi pada kuartal I 2021. SWF atau dalam bahasa Indonesia Lembaga Pengelola investasi setelah dibentuknya diberi nama Indonesia Investment Authority yang disingkat INA (www.kompas.tv com, 2010). Lembaga Pengelola Investasi ini akan mengelola dana investasi dari luar negeri dan dalam negeri sebagai sumber pembiayaan alternatif. Pembentukan Lembaga Pengelola Investasi bertujuan meningkatkan dan mengoptimalkan nilai investasi yang dikelola secara jangka panjang dalam rangka mendukung pembangunan secara berkelanjutan (PP No. 74, 2020). Pembentukan SWF tentunya memberikan keuntungan bagi entitas lainnya terutama entitas BUMN karya yaitu perusahaan yang bergerak pada bidang kontruksi, disebabkan pada periode awal berjalan akan mengutamakan pada sektor jalan tol. Mengamati realitas yang demikian, maka berinvestasi pada emiten kontruksi tentunya memiliki prospek yang cerah kedepannya. Jika melihat emiten BUMN karya yang terdaftar di Bursa Efek Indonesia, setidaknya terdapat 4 (empat) emiten yang listing di pasar modal tersebut yaitu PT Wijaya Karya (Persero) Tbk (WIKA), PT Waskita Karya (Persero) Tbk (WSKT), PT Pembangunan Perumahan (Persero) Tbk (PTPP), dan PT Adhi Karya (Persero) Tbk (ADHI).

Pasar Modal merupakan salah satu bagian dari sistem finansial. Sistem finansial secara garis besar dapat dibagi menjadi dua. Pertama, Financial Intermediaries dan kedua Financial Markets. Sedangkan Financial Markets dapat dibagi menjadi dua yaitu Money Market dan Capital Market. Instrument pasar modal diantaranya Stocks, Mortgages, Corporate Bonds/ Sukuks, Government Securities (Mohd Azmi Omar, Muhamad Abduh, dan Raditya Sukmana), dan lainnya. Keseluruhan instrumen ini merupakan instrumen investasi yang dapat dimanfaatkan oleh masyarakat. Dalam ekspektasi berinvestasi, masyarakat tentunya akan mengharapkan tingkat imbalan yang 
tinggi dari pada investasi yang tersedia. Namun dalam investasi berlaku prinsip high return high risk. Instumen investasi yang menawarkan return yang tinggi salah satunya ialah saham dan tentunya juga menawarkan resiko yang tinggi. Oleh karena itu dalam berinvestasi saham hendaknya melakukan analisa fundamental dalam menilai emiten sebagai tempat investasi. Pada tahun 2021, Bursa Efek Indonesia merubah indeks sektor JASICA dari 9 (Sembilan) sektor ditambah 1 (satu) sektor menjadi indeks sektor 12 (dua belas). Terdapat beberapa sektor pada indeks sektor yang baru yang terdaftar di BEI, diantara salah satunya adalah sektor infrastruktur dimana BUMN karya berada pada sektor ini yang sebelumnya pada indeks JASICA, BUMN karya termasuk sektor properti.

\section{Analisa Fundamental}

Fluktuasi harga saham salah satunya ditentukan oleh sentimen investor (Maulina Agustya \& Faisal, 2018). Sebagaimana misalnya, rencana merger bank syariah pada tahun 2020 yang akhirnya direalisasikan dengan penandatanganan Conditional Merger Agreement antara tiga bank syariah milik Himbara, PT Bank BRIsyariah Tbk, PT Bank Syariah Mandiri, dan PT Bank BNI Syariah (Laporan keterbukaan informasi, 2020). Dampak dari rencana merger bank syariah dan telah ditanda tanganinya Conditional Merger Agreement berdampak pada naik harga saham emiten tersebut (idxchannel.okezone.com, 2020). PT Bank BRIsyariah Tbk merupakan satu - satunya Bank syariah yang akan dimerger yang terdaftar di BEI dengan kode emiten BRIS. Diantara Bank Syariah tersebut hanya BRIS yang terdaftar sebagai Emiten di BEI dan sebagai entitas survivor, sentimen ini melonjakan kenaikan drastis harga saham BRIS selama tiga hari berturut - turut hingga menembus Auto reject Atas sebanyak dua kali. terjadinya Auto reject atas disebabkan batasan kenaikan 25\% (stocksetup.kontan.co.id, 2020) Melambungnya harga saham serta disebabkan dikonfirmasinya rencana merger bank syariah. Selang beberapa hari kemudian justru terjadi Auto reject Bawah dengan penurunan 6,76\%. Berdasarkan data tersebut untuk selanjutnya dapat dianalisa valuasinya, apakah saham tersebut sudah overvalue ataupun undervalue jika kita membandingkan dengan Price to Book Value (PBV) disektornya. Tulisan ini tidak hendak meneliti lebih lanjut hal tersebut, dan menilainya. Akan tetapi sebagai pengantar mengapa menganalisa valuasi suatu saham merupakan hal yang penting. Begitupula halnya dengan dibentuknya SWF juga memberikan sentimen pada harga saham BUMN Karya.

Langkah dalam menentukan valuasi saham, maka biasanya digunakan analisa terhadap rasio PER dan PBV emiten. Rasio ini digunakan untuk menilai valuasi suatu saham apakah saham tersebut over value ataupun undervalue. Undervalue adalah saham yang harga pasarnya lebih rendah dari nilai intrinsiknya (Eduardus Tandelilin ,2010) Selain melihat valuasi suatu saham, hal yang penting juga harus dinilai bagus tidaknya saham tersebut dengan melihat berbagai faktor fundamental misalnya Return on Equity (ROE) (RH Liembono, 2016). Maupun Retun on Assets (ROA). Estimasi nilai intrinsik saham dalam analisis perusahaan bisa dilakukan dengan memanfaatkan dua komponen 
informasi penting dalam analisis perusahaan yaitu EPS dan PER (Eduardus Tandelilin, 2010) Harga saham selalu berfluktuasi sepanjang waktu. Ada yang saham berharga tiga digit sampai lima digit. Terdapat juga saham yang memiliki likuiditas tinggi dan ada juga saham yang diam. Selembar harga saham A berharga 5000, sedangkan saham B seharga 2000. Kita tidak bisa sekedar mengatakan saham A lebih mahal dari pada saham B. murah mahalnya suatu saham tidak ada hubungannya dengan harga saham tersebut ( RH Liembono , 2016) untuk menilainya kita menggunakan rasio harga saham PER dan PBV dimana untuk menilai harga wajar suatu saham dan menilai apakah saham tersebut dapat dikatakan murah ataupun mahal. Per dan PBV yang lebih kecil menunjukan harga saham lebih murah. Permintaan dan penawaran bukanlah satu satunya penentu harga suatu saham. Untuk mengetahuinya setidaknya harus dilakukan Analisis fundamental mengacu pada analisis perusahaan secara terperinci untuk menentukan nilainya (N Gregory Mankiw, 2018 ).

\section{Sovereign Wealth Fund}

Sovereign Wealth Fund adalah dana investasi milik pemerintah berbentuk asset financial, seperti saham, obligasi, property, logam mulia, atau instrumen investasi lainnya. Untuk menghindari kebangkrutan dari Krisis keuangan global tahun 2008, sejumlah lembaga keuangan AS dan Eropa menerima SWF dari pemerintah China dan Negara Arab (Philip Kottler dan John A. caslione, 2011) Negara - Negara Gulf Cooperation Council (GCC) membentuk Sovereign Wealth Fund untuk melakukan diversifikasi daripada kelebihan likuiditasnya demi melakukan pembangunan berkelanjutan kedepanya. Negara GCC dihadapi kenyataan bahwasanya kekayaan andalan Negara GCC yang bersumber daripada minyak merupakan sumberdaya yang terbatas hal ini tentunya akan menghambat pembangunan berkelanjutan jika sumberdaya tersebut akan habis pada saatnya dan tidak dilakukan diversifikasi pada saat kelebihan likuiditas (Erry Wahyu Prasetyo, 2008).

\section{Rasio Valuasi}

Kinerja perusahaan pada umumnya akan diukur dengan laporan keuangan perusahaan seperti neraca (balance sheet), laporan laba rugi, dan arus kas (Didin Fatihudin, 2015) Laporan keuangan yang dipublikasikan dianggap memiliki arti penting dalam menilai suatu perusahaan, karena informasi laporan keuangan tersebut dapat dianalisa apakah emiten tersebut baik atau tidak bagi yang berkepentingan (Wastam W Hidayat, 2018) Menurut fred J. Weston dalam bukunya Arief Sugiono dan Edy untung, rasio keuangan dapat dikelompokan menjadi enam yaitu Rasio likuiditas, rasio leverage, rasio aktivitas, Rasio profitabilitas, Rasio pertumbuhan, dan Rasio Valuasi. Rasio valuasi bertujuan mengukur performa perusahaan secara keseluruhan, karena rasio ini merupakan pencerminan dari rasio risiko dan rasio imbalan hasil (Arief Sugiono dan Edy untung, 2016) Beberapa rasio profitabilitas misalnya Return on Assets (ROA) dan Return on Equity (ROE). 
Rasio profitabilitas bertujuan mengukur efisiensi aktivitas perusahaan dan kemampuan perusahaan untuk memperoleh keuntungan. Misalnya profit margin, gross profit margin, perputaran aktiva, return on investment, dan return on equity (Arief Sugiono, 2008). Rasio Return on assets mengukur tingkat pengembalian dari bisnis atas keseluruhan asset yang ada, Rasio ini sering juga disebut Return on investment (Arief Sugiono, 2008). ROA merupakan jenis rasio untuk mengukur seberapa besar kemampuan sebuah perusahaan dibandingkan dengan total asset. Laba bersih dapat dilihat dari laporan laba rugi, sedangkan total asset dapat dilihat di neraca. ROA yang semakin mendekati 100 persen menunjukan semakin baik. Rumusnya ROA ialah (Didin Fatihudin, 2015):

$$
\mathrm{ROA}=\frac{\text { Laba Bersih }}{\text { Total Aset }}
$$

Return on equity mengukur tingkat pengembalian dari bisnis atas seluruh modal yang ada (Arief Sugiono, Arita Listyandari, dan edy untung, 2008). ROE merupakan rasio untuk mengukur sebesrapa besar kemampuan sebuah perusahaan dalam mencetak laba. Equity (modal) dapat dilihat di neraca. ROE yang semakin mendekati 100 persen menunjukan lebih baik. Rumus ROE ialah (Didin Fatihudin, 2015):

$$
\mathrm{ROE}=\frac{\text { Laba Bersih }}{\text { Modal }}
$$

ROA merupakan cerminan laba dibanding aset. Aset adalah suatu bentuk sumber daya atau pun alokasi dana (investasi) perusahan (David Wijaya , 2017). Secara umum, asset dapat dibagi ke dalam tingkat kelancarannya yaitu asset lancar dan asset tidak lancar. Aset lancar adalah aset yang sifatnya operasional dan rutin. Aset utama pada kelompok aset lancar terdiri dari kas, piutang dan persediaan. Aset tidak lancar merupakan aset yang mempunyai karakter berumur lebih dari satu tahun atau satu siklus usaha. Beberapa jenis aset tidak lancar antara lain aset tetap, aset tidak berwujud, dan investasi (pada perusahaan lain). Aset tetap terbagi menjadi dua kelompok yaitu aset dengan umur terbatas seperti mesin dan aset dengan umur tidak terbatas seperti tanah. Aset tetap yang mempunyai umur terbatas akan disusutkan sedangkan aset dengan umur tidak terbatas tidak akan susut. Aset tak berwujud adalah aset yang tidak mempunyai wujud fisik secara berarti. Komposisi utang dan modal di setiap perusaahaan berbeda. Ada perusahaan yang lebih banyak modalnya, sementara ada perusahaan yang lebih banyak utangnya, untuk tipe kedua adalah perusahaan perbankan (Toto Prihadi, 2019).

Rasio valuasi bertujuan mengukur performa perusahaan secara keseluruhan, karena rasio ini merupakan pencerminan dari rasio risiko dan rasio imbalan hasil. Sebagai suatu perusahaan yang memiliki manajemen baik maka diharapkan PBV dari perusahaan tersebut setidaknya diatas nilai bukunya. Jika PBV perusahaan dibawah satu, maka dapat dinilai bahwa harga saham tersebut adalah dibawah nilai buku (under value) (Arief Sugiono, 2008). Nilai buku diperoleh dari data ekuitas disbanding dengan jumlah sahamnya. Ekuitas adalah hak residual pemegang saham. Ekuitas dapat dibagi berdasarkan sifatnya yaitu Ekuitas yang timbul karena setoran modal pemilik, Ekuitas 
yang timbul dari laba tidak dibagi, dan ekuitas yang timbul karena kegiatan lain seperti gain, selisih kurs penjabaran, dll. Setoran pemilik adalah setoran dari pemegang saham. Saldo laba (retained earning) adalah laba yang diakumulasi sampai saat terakhir. Laba yang diperoleh perusahaan dapat dibagi sebagai dividen atau ditahan di perusahaan. Saldo laba adalah hasil keputusan perusahaan untuk menahan laba (Toto Prihadi, 2019). PBV menggambarkan seberapa besar pasar menghargai nilai buku saham suatu perusahaan. Makin tinggi rasio ini berarti pasar percaya akan prospek perusahaan tersebut (Arief Sugiono, 2008). BVS adalah rasio untuk menilai murah tidaknya sebuah saham dengan saham lainnya, jika hasil BVS-nya lebih kecil ini berarti saham tersebut lebih murah. Rumus BVS ialah (Didin Fatihudin, 2015):

$$
\mathrm{BVS}=\frac{\text { total ekuitas }}{\text { jumlah saham }}
$$

PBV adalah rasio untuk membandingkan harga pasar sebuah saham dengan nilai buku sebenarnya. Semakin kecil hasilnya semakin baik. Rumus PBV ialah (Didin Fatihudin, 2015):

$$
\mathrm{pbv}=\frac{\text { harga saham }}{B V S}
$$

\section{Debt Equity Ratio}

Debt to equty Ratio (DER) merupakan salah satu jenis rasio solvabilitas. Rasio solvabilitas menunjukan tingkat solvabilitas permodalan yang digunakan oleh perusahaan. Rasio ini diuji oleh pemberi pinjaman untuk memperoleh gambaran jelas mengenai risiko yang terjadi jika meminjamkan uang kepada perusahaan dimana pemberi pinjaman akan memperoleh informasi bahwa uang yang mereka pinjamkan akan dibayarkan kembali (Farah Margaretha , 2007). DER sering disebut juga dengan gearing ratio yaitu proporsi pembiayaan utang disbanding dengan ekuitasnya. Dari perspektif kewajiban jangka panjang, semakin rendah rasio DER akan semakin baik yang mana menunjukan kemampuan perusahaan membayar kewajiban jangka panjangnya. Bagi bank, semakin besar rasio DER maka akan semakin tidak menguntungkan karena semakin besar risiko yang ditanggung dari kemungkinan perusahaan membayar utangnya. Jika rasio DER tinggi, akan meningkatkan kemungkinan perusahaan dilikuidasi dan hal ini tidak baik bagi investor dan pemberi pinjaman (Darmawan, 2020).

\section{Kapitalisasi Pasar}

Kapitalisasi pasar adalah nilai pasar dari saham yang diterbitkan (outstanding share) suatu emiten. Kapitalisasi pasar diperoleh dari perkalian jumlah saham yang diterbitkan dengan nilai pasar saham tersebut. Saham yang memiliki kapitalisasi pasar sangat besar dianggap sebagai market mover pergerakan indeks. Nilai kapitalisasi pasar suatu saham terdiri dari beberapa kelompok, yaitu Big Capitalization yaitu kelompok saham yang memiliki nilai kapitalisasi pasar diatas Rp 5 triliun, sifat sahamnya kelompok ini cukup likuid dan biasanya memiliki fundamental yang baik. Kelompok 
saham ini juga biasa disebut saham papan atas, saham lapis pertama. Selanjutnya, kelompok saham mid Capitalization, kelompok ini memiliki nilai kapitalisasi pasar antara 1- 5 triliun. Kelompok saham ini disebut juga saham lapis kedua. Perbedaannya antara saham lapis pertama dan kelompok saham ini terdapat pada harga sahamnya tidak terlalu tinggi dan jumlah saham yang beredar tidak sebanyak saham lapis pertama. Terakhir, kelompok saham mid Capitalization, kelompok saham ini memiliki nilai kapitalisasi pasar dibawah 1 triliun. Kelompok saham ini disebut saham lapis ketiga biasanya banyak diminati investor ritel (Sapto Rahardjo, 2006).

\section{Gambar 1. Kapitalisasi Pasar}

\section{INDONESIA STOCK EXCHANGE} EQUITY DAILY TRADING PUBLICATION
Friday, 12 March 2021 Trading Day 48

\section{STOCK TRADING SNAPSHOT}

\begin{tabular}{|lrr|}
\hline \multicolumn{4}{|c|}{ Top Market } & Cap. (Trill. Rp) \\
\hline 1. BBCA & 826 & $11.1 \%$ \\
2. BBRI & 559 & $7.5 \%$ \\
\hline 3. TLKM & 342 & $4.6 \%$ \\
4. BMRI & 311 & $4.2 \%$ \\
5. UNVR & 256 & $3.4 \%$ \\
6. ASII & 222 & $3.0 \%$ \\
7. TPIA & 189 & $2.5 \%$ \\
\hline 8. HMSP & 167 & $2.2 \%$ \\
9. ARTO & 122 & $1.6 \%$ \\
10. EMTK & 121 & $1.6 \%$ \\
\hline Top 10 & 3,114 & $\mathbf{4 1 . 9} \%$ \\
\hline
\end{tabular}

\begin{tabular}{|lrr|}
\hline \multicolumn{3}{|c|}{ Top Trading Vol. (Mill. Sh) } \\
\hline 1. FREN & 1,785 & $10.7 \%$ \\
2. DOID & 1,463 & $8.7 \%$ \\
3. BWPT & 1,139 & $6.8 \%$ \\
4. BABP & 1,117 & $6.7 \%$ \\
5. BUMI & 909 & $5.4 \%$ \\
6. ABBA & 556 & $3.3 \%$ \\
7. DADA & 542 & $3.2 \%$ \\
8. ANTM & 540 & $3.2 \%$ \\
9. VNA & 463 & $2.8 \%$ \\
10. BULL & 336 & $2.0 \%$ \\
\hline Top 10 & 8,850 & $45.0 \%$ \\
\hline
\end{tabular}

\begin{tabular}{|lrr|}
\hline \multicolumn{3}{|c|}{ Top Trading Value (Bill. Rp) } \\
\hline 1. ANTM & 1,280 & $11.6 \%$ \\
2. BBRI & 715 & $6.5 \%$ \\
3. BBCA & 539 & $4.9 \%$ \\
4. ASII & 537 & $4.9 \%$ \\
5. BMRI & 537 & $4.9 \%$ \\
6. DOID & 533 & $4.8 \%$ \\
7. INCO & 489 & $4.4 \%$ \\
8. TINS & 435 & $3.9 \%$ \\
9. TLKM & 432 & $3.9 \%$ \\
10. TKIIM & 270 & $2.4 \%$ \\
\hline Top 10 & 5,766 & $42.0 \%$ \\
\hline
\end{tabular}

Top Trading Freq. (x)

1. ANTM $70,650 \quad 6.7 \%$

2. DOID $53,287 \quad 5.1 \%$

3. TINS $40,480 \quad 3.9 \%$

4. BABP $34,422 \quad 3.3 \%$

5. BBRI $32,655 \quad 3.1 \%$

6. ABBA $31,579 \quad 3.0 \%$

7. BWPT $27,213 \quad 2.6 \%$

8. INCO $25,453 \quad 2.4 \%$

9. AGRO $23,720 \quad 2.3 \%$

10. ADRO $19,981 \quad 1.9 \%$

\begin{tabular}{l|lr} 
Top 10 & 359,440 & $27.6 \%$
\end{tabular}

Sumber: PT Bursa Efek Indonesia (idx.co.id).

\section{METODE PENELITIAN}

Metode pengumpulan data yang digunakan ialah menggunakan metode dokumentasi yang bersumber dari laporan keuangan kuartal I 2020, kuartal II 2020, dan kuartal III 2020 masing - masing perusahaan yaitu PT Waskita Karya (Persero), Tbk, PT. Wijaya Karya (Persero) Tbk, PT PP (Persero) Tbk dan PT Adhi Karya (Persero) Tbk. Data diperoleh dari website resmi masing - masing perusahaan. Nilai pasar yang digunakan berdasarkan data statistik kuartal II, dan III 2020 yang diperoleh dari website resmi PT Bursa Efek Indonesia, untuk nilai pasar kuartal III 2020 menggunakan nilai pasar pada tanggal 24 Februari 2021. Dari data tersebut, kemudian akan dianalisa fundamental menggunakan rasio valuasi dan rasio solvabilitas. 
IHTIYATH Jurnal Manajemen Keuangan Syariah

Vol. 5 No. 1, September 2021

\section{HASIL DAN PEMBAHASAN}

Untuk menilai valuasi saham suatu emiten, rasio yang biasa digunakan ialah PER dan PBV. Jumlah saham PT Waskita Karya (Persero) Tbk (WSKT) sebanyak 13.573.951.000 lembar (www.idx.co.id, 2020). berdasarkan laporan keuangan kuartal 3 2020 PT Waskita Karya (Persero) Tbk, WSKT mengalami rugi bersih sebesar Rp. 2.636.970.538.731. dari data tersebut dapat diketahui Earning per Share (EPS) WSKT yaitu -193,89. Nilai pasar WSKT sebesar Rp1.465 perlembar, maka PER WSKT adalah -7,56. Jumlah ekuitas WSKT sebesar Rp. 23.767.190.438. Maka diperoleh Book Value per Share (BVpS) WSKT yaitu 1750,94. Hal ini menunjukan Price to Book Value (PBV) WSKT ialah 0,84x. untuk lebih jelasnya mengenai perkembangan WSKT periode 2020 dapat dilihat pada tabel 1.

Gambar 2. Price to Book Value WSKT Periode 2020

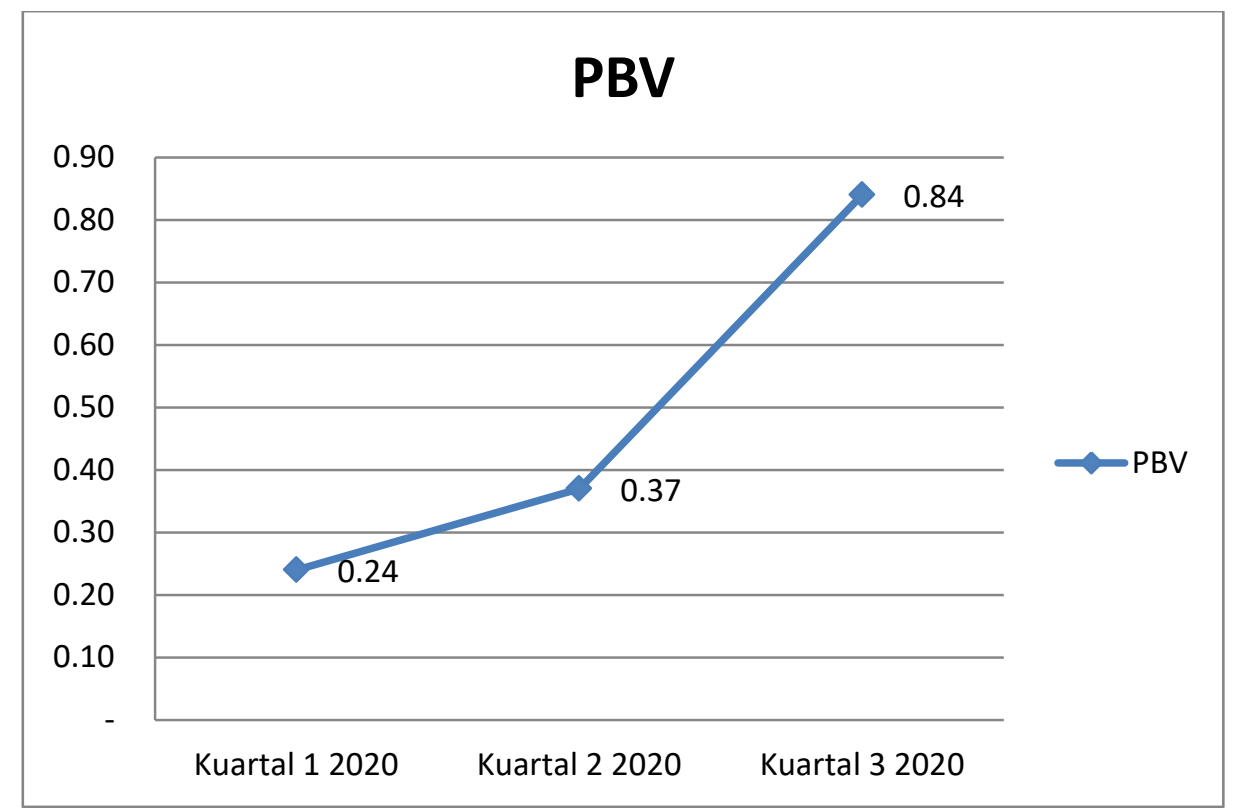

Sumber: Laporan Keuangan WSKT periode 2020

Berdasarkan grafik diatas menunjukan bahwasanya, Price to book value PT Waskita Karya (Persero) Tbk pada kuartal 1 memiliki nilai 0,24. Pada kuartal I menunjukan valuasi emiten PT Waskita Karya (Persero), Tbk tergolong undervalue, yang mana menunjukan harga pasar PT Waskita Karya (Persero) Tbk berada dibawah book valuenya yaitu sebesar 2009,00 sedangkan harga pasar kuartal I berada pada harga 484. Pada kuarta II, price to book value PT Waskita Karya mengalami peningkatan menjadi 0,37. Secara valuasi, nilai ini masih berada dalam kategori undervalue disebabkan nilai price to book value masih berada dibawah 1 (satu). Peningkatan price to book value disebabkan adanya peningkatan pada harga pasar yaitu dari 484 pada kuartal I, menjadi 710 pada kuartal II. Peningkatan price to book value disamping disebabkan meningkatnya harga pasar, juga disebabkan menurunnya book value PT Waskita Karya (Persero) Tbk, dari semula pada kuartal I sebesar 2009,00 menjadi 
1902,46 pada kuartal II 2020. Penurunan Book value per share disebabkan oleh karena menurunnya Equity PT Waskita Karya (Persero) Tbk menjadi 25.823.891.390 pada kuartal II. Sedangkan pada kuartal III 2020, harga pasar PT Waskita Karya (Persero) Tbk meningkat menjadi 1465. Peningkatan harga pasar turut pula meningkatkan price to book value PT Waskita Karya (Persero) Tbk menjadi 0,84. Untuk lebih jelasnya dapat dilihat pada tabel 1 dibawah ini.

Tabel 1. WSKT Periode 2020

\begin{tabular}{lrrr}
\hline \multicolumn{1}{c}{$\begin{array}{c}\text { Dalam } \\
\text { Ribuan }\end{array}$} & \multicolumn{1}{c}{ Kuartal I } & \multicolumn{1}{c}{ Kuartal II } & \multicolumn{1}{c}{ Kuartal III } \\
\hline Equity & 27.270 .050 .126 & 25.823 .891 .390 & 23.767 .190 .438 \\
Nilai Pasar & 484 & 710 & 1465 \\
Share & 13.573 .951 & 13.573 .951 & 13.573 .951 \\
BV & 2009,00 & 1902,46 & 1750,94 \\
PBV & 0,24 & 0,37 & 0,84 \\
Earning & 42.696 .351 & $(1.095 .094 .638)$ & $(2.636 .970 .539)$ \\
EPS & 3,14 & $-80,52$ & $-193,89$ \\
PER & 154,14 & $-8,82$ & $-7,56$ \\
Liabilitas & 89.095 .812 .601 & 88.248 .305 .812 & 91.861 .232 .033 \\
DER & 3,27 & 3,42 & 3,87 \\
Market Cap & 6.569 .792 .284 & 9.637 .505 .210 & 19.885 .838 .215 \\
\hline
\end{tabular}

Emiten yang selanjutnya ialah PT Wijaya Karya (Persero) Tbk. Jumlah saham WIKA sebanyak 8.969.951.372 lembar. Dengan laba tahun berjalan 50.192.044. EPS WIKA yaitu 5,60. Harga saham WIKA 1795, maka PERnya yaitu 320,79. Jumlah ekuitas WIKA ialah 16.169.896.448 jika dibagi dengan jumlah saham yang beredar akan mendapatkan nilai BVps WIKA sebesar 1802,67. dengan Pbv sebesar 1,00. Untuk selengkapnya mengenai pergerakan WIKA dapat dilihat pada tabel 2. 
IHTIYATH Jurnal Manajemen Keuangan Syariah

Vol. 5 No. 1, September 2021

Gambar 3. Price to Book Value WIKA Periode 2020

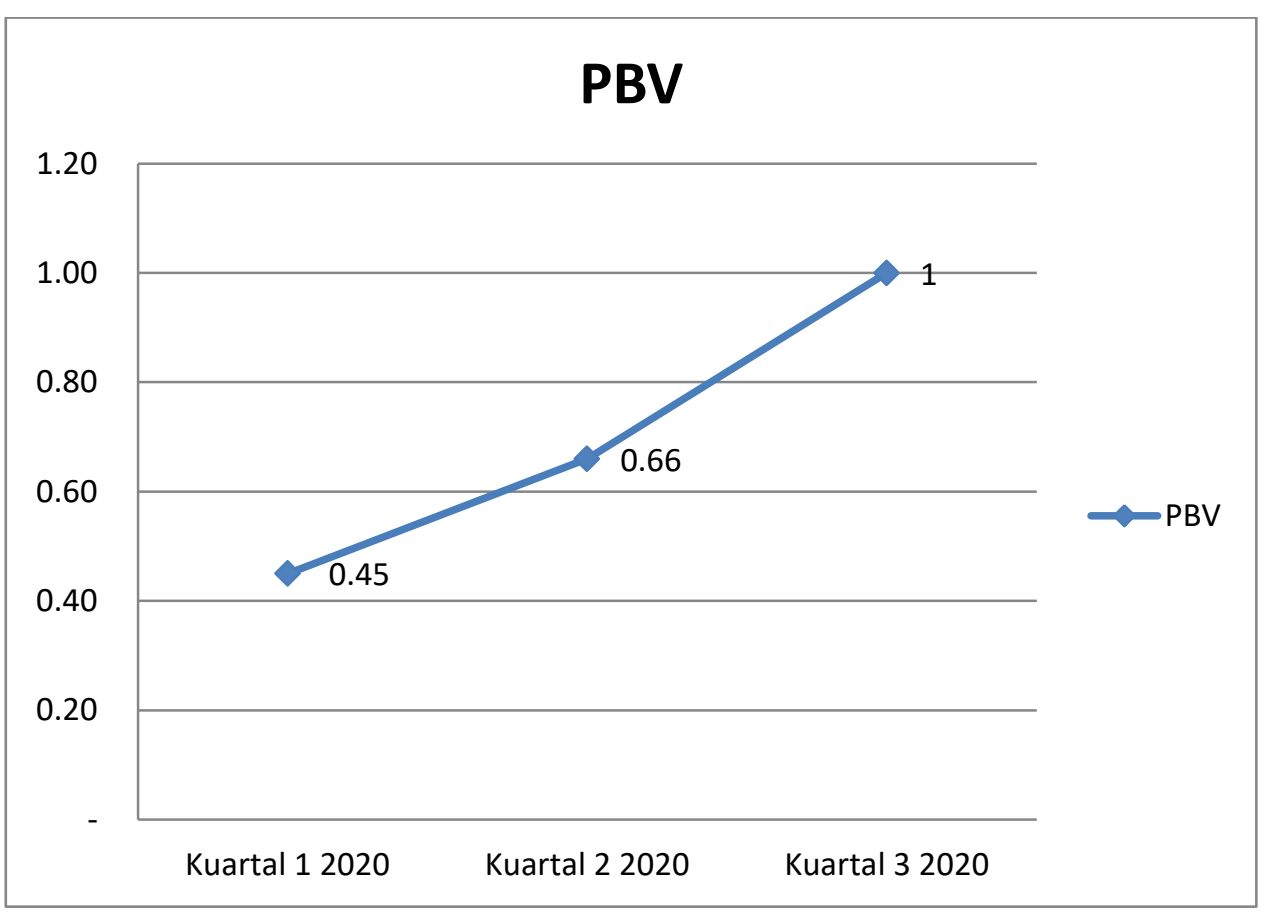

Sumber: Laporan Keuangan Wijaya Karya, Tbk

Emiten PT Wijaya Karya (Persero) Tbk, mencatatkan price to book value dengan nilai 0,45 pada kuartal I 2020. Pada kuartal II 2020, terjadi peningkatan nilai price to book value menjadi 0,66. Hal ini terjadi disebabkan adanya kenaikan harga pasar PT Wijaya Karya (Persero) Tbk menjadi 1200 pada kuartal II 2020 dan diikuti dengan penurunan equity yang mengakibatkan penurunan book value per share. Pada kuartal III 2020, peningkatan harga pasar menjadi 1795 sehingga price to book value dari semula 0,66 menjadi 1,00. Diantara emiten karya yang terdaftar di Bursa Efek Indonesia, PT Wijaya Karya (Persero) Tbk termasuk salah satu emiten yang berada pada indeks LQ45 yang menjadikan salah satu emiten karya yang tergolong likuid. Pada kuartal III 2020, PT Wijaya Karya (Persero) Tbk mengalami penurunan laba bersih dari semula 250,415,303 pada kuartal II 2020 menjadi 50.192.044 pada kuartal III 2020. Namun penurunan ini tidak mengakibatkan PT Wijaya Karya (Persero) Tbk mengalami rugi bersih. Penurunan income PT Wijaya Karya (Persero) Tbk mengakibatkan penurunan earning per share emiten tersebut, dari semula earning per share dengan nilai 27,82 menjadi 5,60. Penurunan earning per share berdampak pada meningkatnya PER PT Wijaya Karya (Persero) Tbk menjadi 320,79. Untuk lebih lengkap dan jelas, dapat dilihat pada tabel berikut ini. 
Tabel 2. WIKA Periode 2020

\begin{tabular}{lrrr}
\hline \multicolumn{1}{c}{$\begin{array}{c}\text { Dalam } \\
\text { Ribuan }\end{array}$} & \multicolumn{1}{c}{ Kuartal I } & Kuartal II & \multicolumn{1}{c}{ Kuartal III } \\
\hline Equity & 16.791 .770 .681 & 16.223 .892 .679 & 16.169 .896 .448 \\
Nilai Pasar & 835 & 1200 & 1795 \\
Share & 8.969 .951 & 8.969 .951 & 8.969 .951 \\
BV & 1872,00 & 1808,69 & 1802,67 \\
PBV & 0,45 & 0,66 & 1,00 \\
Earning & 99.213 .547 & $250,415,303$ & 50.192 .044 \\
EPS & 11,02 & 27,82 & 5,60 \\
PER & 75,77 & 43,13 & 320,79 \\
Liabilitas & 44.324 .675 .585 & $43,870,646,516$ & 45.260 .555 .790 \\
DER & 2,64 & 2,70 & 2,80 \\
Market Cap & 7.489 .909 .085 & 10.763 .941 .200 & 16.101 .062 .045 \\
\hline
\end{tabular}

Ketiga, yaitu emiten PT Pembangunan Perumahan (Persero) Tbk. Jumlah lembar saham PTPP setelah melakukan right issue atau Hak memesan Efek terlebih dahulu (HMETD) pada tanggal 27 Desember 2016 sebesar lembar 6.199.897.354 (www.idc.co.id, 2020). sedangkan laba tahun berjalan PTPP sebesar 26.367.494.584 (Laporan Keuangan PTPP, 2020). EPS PTPP disetahunkan diperoleh dari (26.367.494.584 : 3/4) dibagi 6.199.897.354 maka diperoleh nilai Earning per Share PTPP disetahunkan sebesar 5,67. Setelah diketahui nilai EPS, maka selanjutnya dapat diidentifikasi valuasi PER PTPP. PER PTPP diperoleh dengan membagi harga penutupan dibagi dengan EPS. Untuk harga penutupan dipakai harga penutupan per tanggal 24 Februari 2021 yaitu 1660. Maka nilai PER PTPP adalah 1660/5,67 yaitu 292,77. Disamping PER, valuasi juga dapat dianalisa dengan PBV. Mencari PBV, terlebih dahulu mengidentifikasi nilai Book Value per share. bVps diperoleh dengan melihat laporan keuangan PTPP kuartal III 2020 pada nilai ekuitas yang dapat diatribusikan kepada entitas induk yaitu sebesar 10.927.317.779.394. selanjutnya nilai ekuitas dibagi jumlah saham. Maka diperoleh BVps PTPP sebesar 1.762,5. Nilai PBv diperoleh dengan membagi harga saham penutupan pertanggal 24 Februari 2021 dibagi dengan book value maka diperoleh pbv PTPP sebesar 0,94. 
IHTIYATH Jurnal Manajemen Keuangan Syariah

Vol. 5 No. 1, September 2021

Gambar 4 Price to Book Value PTPP Periode 2020

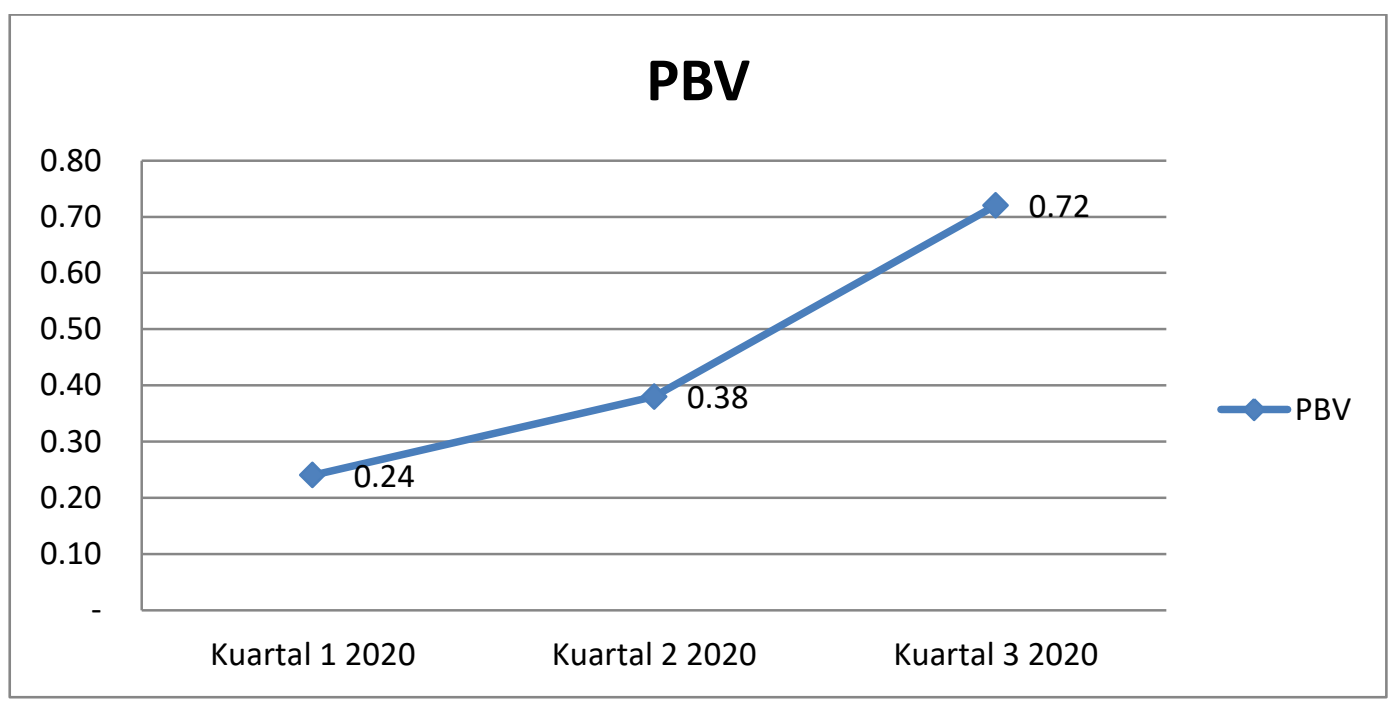

Sumber: Laporan Keuangan PTPP

PT Pembangunan Perumahan (Persero) Tbk merupakan emiten terindeks LQ45 menemani PT Wijaya Karya (Persero) Tbk. PT Pembangunan Perumahan (Persero) Tbk memiliki kapitalisasi pasar kedua yang terkecil jika dibandingkan dengan PT Waskita Karya (Persero) Tbk, PT Wijaya Karya Tbk dan PT Adhi Karya (Persero) Tbk. Melihat dari income, PT Pembangunan Perumahan (Persero) Tbk, hingga kuartal III 2020 tidak mengalami rugi bersih ataupun penurunan laba bersih sebagaimana PT Waskita Karya (Persero) Tbk dan PT Wijaya Karya (Persero) Tbk. Dari segi solvabilitas, debt to equty ratio PT Pembangunan Perumahan (Persero) Tbk pada periode 2020 terus mengalami penurunan, yang mana hal ini menunjukan kemajuan yang positif bagi PT Pembangunan Perumahan (Persero) Tbk yang terus menurunkan liabilitasnya. walaupun demikian, debt to equity ratio dengan nilai 2,79 pada kuartal III 2020, masih tergolong tinggi disebabkan liabilitasnya masih berada diatas nilai ekuitasnya. Untuk lebih jelasnya dapat dilihat pada tabel 3 dibawah ini.

Tabel 3. PTPP Periode 2020

\begin{tabular}{lrrr}
\hline \multicolumn{1}{c}{$\begin{array}{c}\text { Dalam } \\
\text { ribuan }\end{array}$} & \multicolumn{1}{c}{ Kuartal I } & \multicolumn{1}{c}{ Kuartal II } & \multicolumn{1}{c}{ Kuartal III } \\
\hline Equity & 14.164 .047 .880 & 14.199 .680 .936 & 14.252 .845 .144 \\
Nilai Pasar & 550 & 870 & 1660 \\
Share & 6.199 .897 & 6.199 .897 & 6.199 .897 \\
$B V$ & 2284,56 & 2290,31 & 2298,88 \\
$P B V$ & 0,24 & 0,38 & 0,72
\end{tabular}




\begin{tabular}{lrrr} 
Earning & 13.319 .845 & 15.944 .404 & 26.367 .495 \\
EPS & 2,15 & 2,57 & 4,25 \\
PER & 256,00 & 338,29 & 390,32 \\
Liabilitas & 40.565 .043 .349 & 39.919 .419 .325 & 39.763 .288 .587 \\
DER & 2,86 & 2,81 & 2,79 \\
Market Cap & 3.409 .943 .350 & 5.393 .910 .390 & 10.291 .829 .020 \\
\hline
\end{tabular}

Dari hasil analisa laporan keuangan diatas dapat dilihat bahwasanya, Kapitalisasi Pasar terbesar dimiliki oleh PT Waskita Karya (Persero) Tbk, selanjutnya diikuti oleh PT Wijaya Karya (Persero) Tbk, kemudian Pembangunan Perumahan (Persero) Tbk dan ditutup oleh PT Adhi Karya (persero) Tbk. Rasio valuasi Price to Book Value terendah dimiliki oleh PT Pembangunan Perumahan (Persero) Tbk dan diakhiri oleh PT Waskita Karya (Persero) Tbk, dimana PT Waskita Karya (Persero) Tbk memiliki nilai PBV negatif disebabkan memiliki laba bersih yang negatif pada periode 2020 .

Emiten karya terakhir yang terdaftar di Bursa Efek Indonesia ialah PT Adhi Karya (Persero) Tbk. Untuk melihat perkembangan price to book value PT Adhi Karya (Persero) Tbk dapat dilihat pada gambar dibawah ini.

Gambar 5. Price to Book Value ADHI Periode 2020

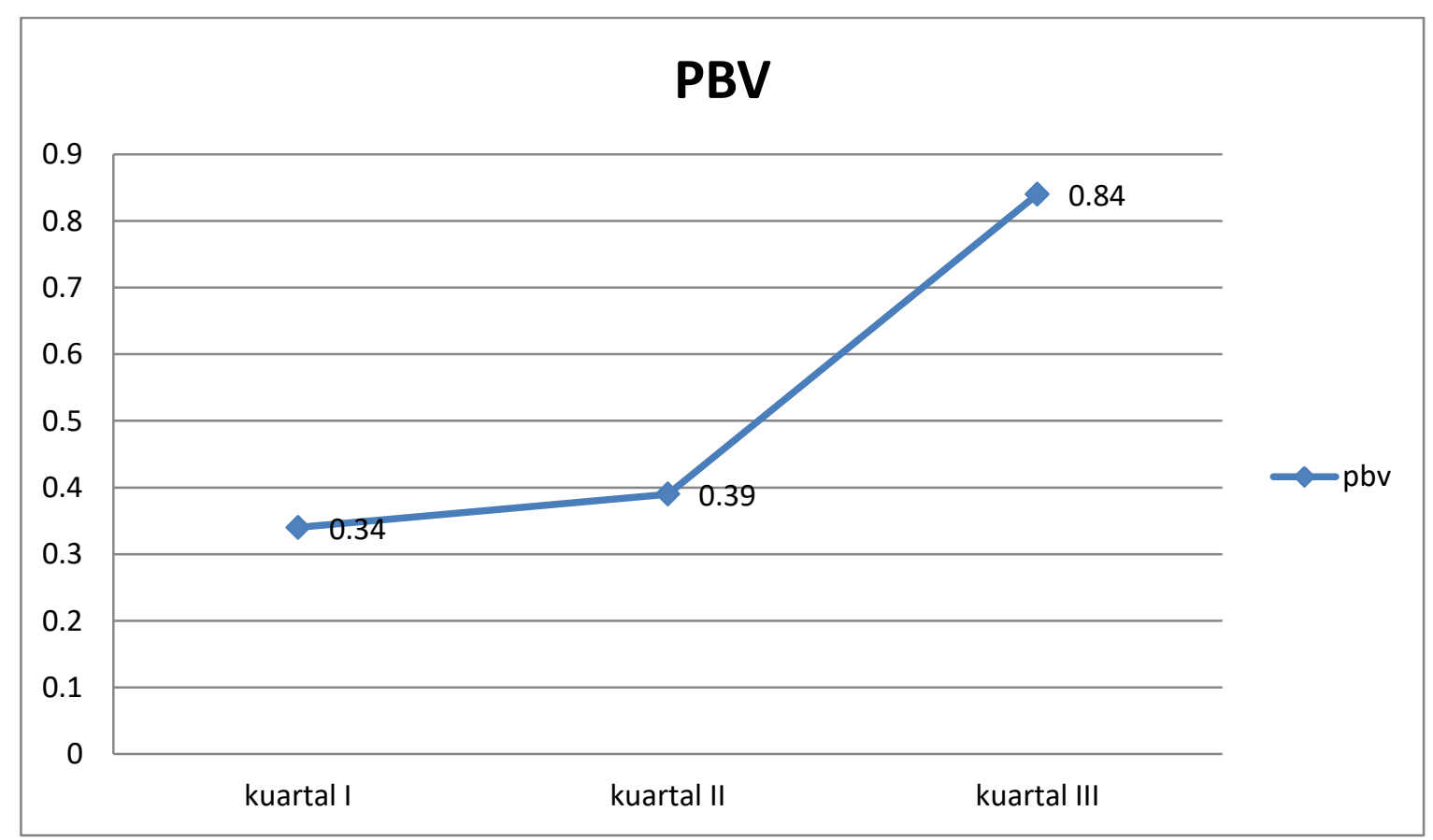

Sumber: Laporan Keuangan PT Adhi Karya (Persero) Tbk 
IHTIYATH Jurnal Manajemen Keuangan Syariah

Vol. 5 No. 1, September 2021

Dari gambar diatas, dapat dijelaskan bahwasanya sepanjang tiga kuartal periode 2020. Price to book value terus meningkat mengikuti kenaikan harga pasar. Peningkatan ekuitas PT Adhi Karya (Persero) Tbk terjadi pada kuartal III 2020, sedangkan pada kuartal II mengalami penurunan pada ekuitas.

Tabel 4. ADHI Periode 2020

\begin{tabular}{lrrr}
\hline \multicolumn{1}{c}{$\begin{array}{c}\text { Dalam } \\
\text { ribuan }\end{array}$} & Kuartal I & Kuartal II & \multicolumn{1}{c}{ Kuartal III } \\
\hline Equity & 5.670 .999 .290 & 5.518 .283 .879 & 5.586 .669 .791 \\
Nilai Pasar & 535 & 610 & 1320 \\
Share & 3.560 .849 & 3.560 .849 & 3.560 .849 \\
BV & 1584,03 & 1579,77 & 1568,91 \\
PBV & 0,34 & 0,39 & 0,84 \\
Earning & 9.147 .225 & 6.904 .012 & 15.383 .964 \\
EPS & 4,04 & 3,13 & 4,32 \\
PER & 132,43 & 194,89 & 305,43 \\
Liabilitas & 1.905 .054 .215 & 2.172 .117 .890 & 4.700 .320 .680 \\
DER & 5,48 & 32.121 .311 .596 & 31.965 .101 .583 \\
Market Cap & & & \\
\hline
\end{tabular}

Dari keempat emiten karya, PT Adhi karya (Persero) Tbk memiliki nilai pasar yang terendah pada kuartal III 2020 yaitu 1320. Namun, nilai pasar yang rendah tidak menunjukan bahwasanya emiten ini undervalue . nilai price to book value PT Adhi Karya (Persero) Tbk masih lebih tinggi jika dibandingkan dengan PT Pembangunan Perumahan (Persero) Tbk sehingga nilai pasar tidak dijadikan acuan utama dalam menilai valuasi suatu emiten

\section{KESIMPULAN}

Diantara keempat emiten karya yaitu PT Waskita Karya (Persero) Tbk, PT Wijaya Karya (Persero) Tbk, PT Pembangunan Perumahan (Persero) Tbk dan PT Adhi Karya (Persero) Tbk, maka dapat disimpulkan bahwasanya PT Pembangunan Perumahan (Persero) Tbk memiliki valuasi terendah pada kuartal III 2020. Begitu juga dengan rasio 
solvabilitas, PT Pembangunan Perumahan (Persero) Tbk memiliki nilai Debt to Equity Ratio yang lebih baik dari ketiganya. Hal ini menunjukkan emiten tersebut memiliki kemampuan menyelesaikan kewajiban yang lebih baik, akan tetapi rasio Debt to Equity Ratio tetap masih kategori tinggi disebabkan memiliki nilai diatas 1 (satu) serta PER yang tertinggi dari keempat emiten karya tersebut dengan nilai 390,32 pada kuartal III 2020 dimana earning per share sebesar 4,25. Dari segi kapitalisasi pasar, PT Waskita Karya (Persero) Tbk memiliki market Capitalization yang terbesar dari seluruh emiten karya, sedangkan PT Adhi Karya (Persero) Tbk memiliki kapitalisasi pasar yang terendah.

\section{DAFTAR PUSTAKA}

Agustya, Maulina., Faisal. Sentimen Investor dan Ekspektasi pertumbuhan laba jangka panjang pada industry non keuangan di Indonesia dalam Jurnal Ilmiah Mahasiswa Ekonomi Manajemen vol, 3 No. 12018

Darmawan, dasar - dasar memahami rasio dan laporan keuangan, Yogyakarta: UNY Press, 2020

Fatihudin, Didin, metode penelitian : untuk ilmu ekonomi, manajemen dan akuntansi, Sidoarjo: zifatama publisher, 2015

Hidayat, wastam wahyu, dasar - dasar analisa laporan keuangan, Ponorogo, Uwais Inspirasi Indonesia, 2018

Kompas.com, ingin tahu rancangan induk sovereign wealt fund" http:// www.kompas.tv/article/139371/ingin-tahu-rancangan-induk-sovereign-wealthfund-indonesia-ini-paparan-menteri-keuangan-sri-mulyani diakses pada tanggal 19 Januari 2021

Kontan.co.id, lagi saham bri syariah auto rejection atas harga melambung" http:// https://stocksetup.kontan.co.id/news/lagi-saham-bri-syariah-bris-autorejection-atas-ara-harga-melambung?page=all diakses pada tanggal 14 Oktober 2020

Kottler, Philip dan John A. Caslione, Chaotics: resep jitu bertahan diabad prahara dari pakar pemasaran dunia, Jakarta: PT Gramedia Pustaka Utama, 2011

Liembono, RH, Analisis Fundamental 2, Surabaya: Brilliant, 2016

Laporan Keuangan Triwulan I, II dan III PT Adhi Karya (Persero), Tbk, 2020

Laporan Keuangan Triwulan I, II dan III PT Pembangunan Perumahan (Persero), Tbk, 2020

Laporan Keuangan Triwulan I, II dan III PT Waskita Karya (Persero), Tbk, 2020

Laporan Keuangan Triwulan I, II dan III PT Wijaya Karya (Persero) Tbk, 2020

Mankiw, N Gregory, Pengantar Ekonomi Makro, Jakarta: Salemba Empat, 2018

Margaretha, Farah, Manajemen Keuangan bagi industri jasa, Jakarta: Grasindo, 2007

https://journal.iainlangsa.ac.id/index.php/ihtiyath/article/view/2633

https://doi.org/10.32505/ihtiyath.v5i1.2633 
IHTIYATH Jurnal Manajemen Keuangan Syariah

Vol. 5 No. 1, September 2021

Okezone.com, Masih terdongkrak sentimenmerger 3 bank syariah BUMN" http:// Saham BRIS Naik 24,89\%, Masih Terdongkrak Sentimen Merger 3 Bank Syariah BUMN diakses pada tanggal 14 Oktober 2020

Omar, Mohd Azmi dkk. Fundamentals of Islamic Money and Capital Markets, Singapore: John Wiley \& Sons Singapore, $\mathrm{tt}$

PP No. 74 Tahun 2020 Tentang Lembaga Pengelola Investasi

Prasetyo, Erry Wahyu, sovereign wealth fund sebagai pengelola kelebihan likuiditas di Negara - Negara gulf cooperation council, dalam jurnal Global dan strategis volume, 2 No.2 2008).

Prihadi, toto, Analisis Laporan keuangan : Konsep dan aplikasi, Jakarta: PT Gramedia Pustaka Utama, 2019

Rahardjo, Sapto, kiat membangun asset kekayaan, Jakarta: PT Elex Media Komputindo, 2006

Setkab.go.id, pemerintah terbitkan pp tentang lembaga pengelola investasi" http:// setkab.go.id/pemerintah-terbitkan-pp-tentang-lembaga-pengelola-investasi diakses pada tanggal 17 Desember 2020

Sugiono, Arief, Arita Listyandari, dan edy untung, Panduan praktis Dasar Analisa Laporan keuangan, Jakarta: Grasindo, 2018

Tambunan, Andy porman, Menilai harga wajar saham (stock valuation), Jakarta: PT Elex Media Komputindo, 2008

Tandelilin, Eduardus, Portofolio dan Investasi. Yogyakarta: Kanisius, 2010

Wijaya, David, Manajemen Keuangan Konsep dan Penerapannya, Jakarta: Pt Grasindo, 2017 